\title{
Inventarisasi Jamur Makroskopis Pada Habitat Rawa Gambut di Kawasan Cabang Panti Taman Nasional Gunung Palung Kalimantan Barat
}

\author{
Ogi Prayogo ${ }^{1 *}$, Rahmawati ${ }^{1}$, Mukarlina $^{1}$ \\ ${ }^{1}$ Program Studi Biologi, Fakultas MIPA, Universitas Tanjungpura, \\ Jl. Prof. Dr. H. Hadari Nawawi, Pontianak \\ *Email Korespondensi : masteryogi94@gmail.com
}

\begin{abstract}
This inventory needs to be carried out to determine the types of macroscopic fungi that are found in the Peat Swamp Habitat of the Cabang Panti Gunung Palung National Park. Taking mushroom samples using the Purposive sampling method and roaming method by tracing the path. Identification is carried out based on macroscopic characters. Based on the results of the inventory at the Cabang Panti of Gunung Palung National Park, there were 3 macroscopic fungi from the Order of Agaricales, Auriculariales and Polyporales which which has three species including Auricularia auricula, auricularia delicata, Lichenomphalia sp. and Microporus xanthopus
\end{abstract}

Keywords : Macroscopic Fungi, Auricularia, Lichenomphalia, Microporus

\section{PENDAHULUAN}

Tanah gambut merupakan tanah yang terdiri dari lapisan bahan organik yang memiliki ketebalan 50 $\mathrm{cm}$ hingga lebih. Tanah gambut belum melapuk secara sempurna karena disebabkan oleh kondisi jenuh dengan air dan miskin akan unsur hara. Tanah ini terbentuk dari hasil pelapukan tumbuhtumbuhan yang telah mati tetapi belum terurai dengan sempurna, hal ini disebabkan karena proses dekomposisi terhambat dalam keadaan anaerob dan kondisi lainnya yang dapat menghambat kehidupan biota pengurai (Agus \& Subiksa, 2008).

Jamur makroskopis adalah salah satu dari komponen penting ekosistem hutan. Peran jamur makroskopis bagi ekosistem adalah sebagai dekomposer (pengurai) yang mempercepat siklus materi dalam ekosistem hutan dengan memainkan peran penting pada daur ulang nutrisi (Tapwal et al., 2013). Jamur makroskopis dapat ditemukan di berbagai bahan organik seperti tanah, humus, kayu, serasah dan kotoran hewan (Widhiastuti \& Nurtjahja, 2013).

Jamur Auricularia memiliki banyak kandungan nutrisi dan manfaat. Menurut Prihati (2011) dalam Nurilla et al. (2013) Kandungan yang terdapat dalam jamur Auricularia terdiri dari protein, lemak, karbohidrat, riboflavin, niacin, $\mathrm{Ca}, \mathrm{K}, \mathrm{P}, \mathrm{Na}$ dan $\mathrm{Fe}$. Jamur Auricularia diketahui dapat menjadi bahan pengental makanan dan penetral racun. Manfaat lain dari jamur ini bisa digunakan untuk pengobatan penyakit jantung koroner, mengurangi kekentalan darah dan mengurangi resiko penyumbatan pembuluh darah yang dapat terjadi di otak (Nurilla et al., 2013). Microporus xanthopus mengandung banyak Polifenol, Alkaloid, Proanthocyanidins dan Kumarin yang bermanfaat sebagai anti oksidan dan anti karsinogenik. Mengatasi penyakit radang, kardiovaskular dan neurodegeneratif (Ornely, et al., 2018).

Taman Nasional Gunung Palung sebagian besar merupakan kawasan berupa hutan primer dan memiliki banyak komunitas tumbuhan serta satwa liar. Taman Nasional ini adalah salah satu kawasan pelestarian alam yang memiliki keanekaragaman hayati bernilai tinggi, dan berbagai tipe habitat salah satunya hutan rawa gambut (Cannon \& Leighton, 2004; Cannon et al., 2007).

Inventarisasi mengenai jamur makroskopis di Kalimantan barat pada hutan rawa gambut sudah pernah dilakukan oleh Wahyudi et al. (2012) di Desa Teluk Bakung, Kecamatan Sungai Ambawang, Kabupaten Kubu Raya yang menemukan Ordo Agaricales, Auriculariales dan Polyporales. Hingga saat ini diperkirakan masih banyak spesies dari kelompok jamur makroskopis yang belum teridentifikasi di wilayah Kalimantan Barat, khususnya Taman Nasional Gunung Palung. Informasi mengenai berbagai jenis jamur di Habitat Rawa Gambut Taman Nasional Gunung Palung (TNGP) masih belum diketahui, bahkan belum 
ditemukan penelitian tentang inventarisasi jamur makroskopis di kawasan Habitat Rawa Gambut TNGP khususnya di Cabang Panti, Kalimantan Barat. Oleh karena itu, perlu dilakukan penelitian untuk mengetahui jenis-jenis jamur makroskopis yang ada di habitat tersebut.

\section{BAHAN DAN METODE}

\section{Bahan}

Bahan yang digunakan untuk penelitian ini adalah alkohol $70 \%$

\section{Tempat dan Waktu Penelitian}

Pengambilan sampel dilakukan di Habitat Rawa Gambut Taman Nasional Gunung Palung daerah Cabang Panti, Kabupaten Kayong Utara, Kalimantan Barat. Identifikasi dilakukan di Laboratorium Biologi, Jurusan Biologi Fakultas Matematika dan Ilmu Pengetahuan Alam, Universitas Tanjungpura, Pontianak. Penelitian berlangsung mulai dari bulan November 2016 sampai bulan Desember 20

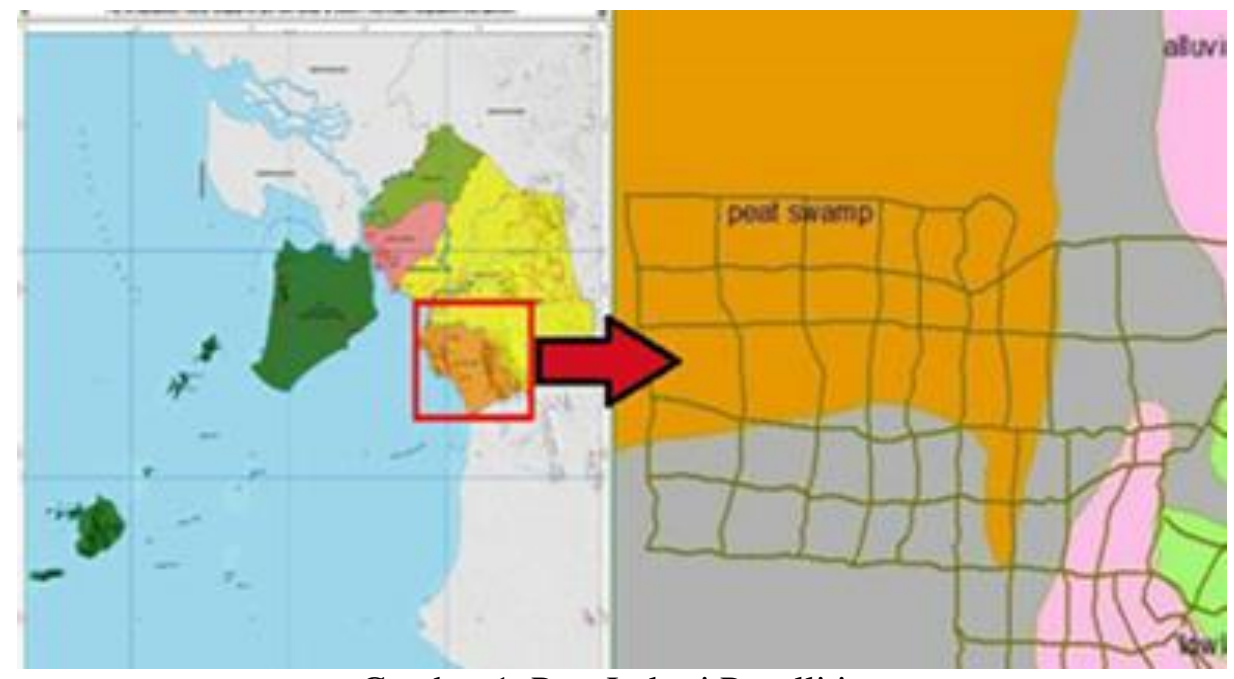

Gambar 1. Peta Lokasi Penellitian

\section{Cara Kerja}

\section{Pengambilan Sampel Jamur}

Penentuan lokasi pada saat pengambilan sampel jamur makroskopis dilakukan menggunakan metode purposive sampling (Darwis et al., 2011). Pengambilan sampel dilakukan dengan jelajah (Sundra, 2016) di sekitar area lokasi yang telah ditentukan pada semua tipe habitat. Sebelum pengambilan jamur dari batang kayu, serasah atau tanah, terlebih dahulu dilakukan pendataan jamur makroskopis yang meliputi bentuk tudung, tekstur tudung, tepian tudung, lebar tudung, tinggi tudung, bentuk bilah, warna tudung, ada tidaknya tangkai, bentuk tangkai, panjang tangkai, lebar tangkai dan warna tangkai. Faktor lingkungan yang dapat mempengaruhi pertumbuhan jamur makroskopis juga dilakukan pengukuran seperti ketinggian tempat, suhu, kelembaban, intensitas cahaya matahari dan substrat tumbuh.

\section{Identifikasi Jamur Makroskopis}

Identifikasi jamur makroskopis dilakukan di laboratorium Biologi FMIPA UNTAN dengan mengacu pada buku A Field Guide to Mushrooms
North America (McKnight \& McKnight, 1987), The Complete Encyclopedia of Mushrooms (Keizer, 2007), North American Mushrooms (Miller \& Miller, 2006) dan Cendawan (Widhiastuti \& Nurtjahja, 2013), serta beberapa referensi ilmiah lainnya.

Identifikasi dilakukan dengan memperhatikan kesamaan karakter morfologis yang terlihat pada jamur dan diamati dengan menggunakan referensi acuan. Sampel jamur makroskopis yang telah diambil diawetkan dengan membuat herbarium kering dan basah. Jamur yang akan dibuat herbarium dikering anginkan dan disemprot dengan alkohol $70 \%$. Pembuatan herbarium basah dengan cara sampel jamur dimasukkan ke dalam botol kaca kemudian diberi alkohol $70 \%$ dan ditutup dengan rapat.

\section{Analisis Data}

Data yang telah diperoleh dari hasil penelitian dianalisa secara deskriptif. Analisa secara deskriptif dilakukan melalui hasil pengamatan ciri-ciri morfologis dari setiap sampel jamur yang didapat. 


\section{HASIL DAN PEMBAHASAN}

\section{Hasil}

Berdasarkan hasil dari inventarisasi di habitat rawa gambut, Cabang Panti Taman Nasional Gunung Palung, didapatkan 4 jenis jamur makroskopis dari anggota ordo Agaricales, Auriculariales dan Polyporales (Tabel 1). Spesies dari ketiga Ordo tersebut terdiri dari spesies Lichenomphalia sp., Auricularia auricula, Auricularia delicata dan Microporus xanthopus (Gambar 2).
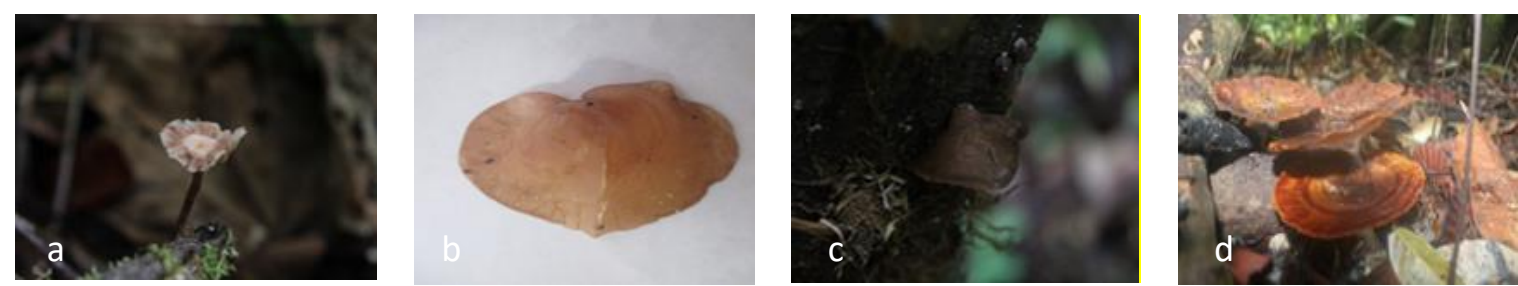

Gambar 2. Jamur makroskopis Ordo Agaricales : (a.) Lichenomphalia sp., Ordo Auriculariales: (b.) Auricularia auricula, (c.) Auricularia delicata dan Ordo Polyporales : Microporus xanthopus

Tabel 1. Jenis Jamur Makroskopis Ordo Agaricales, Auriculariales dan Polyporales di Habitat Rawa Gambut Kawasan Cabang Panti Taman Nasional Gunung Palung

\begin{tabular}{|c|c|c|c|c|c|c|}
\hline \multirow[b]{2}{*}{ No } & \multirow{2}{*}{ Ordo } & \multirow{2}{*}{ Genus } & \multirow{2}{*}{ Spesies } & \multicolumn{3}{|c|}{ Substrat Tumbuh } \\
\hline & & & & $\mathbf{T}$ & $\mathbf{B L}$ & $\mathbf{R L}$ \\
\hline 1. & Agaricales & Lichenomphalia & Lichenomphalia sp. & - & + & - \\
\hline 2. & Auriculariales & Auricula & Auricularia auricula & - & + & - \\
\hline & & & Auricularia delicata & - & + & - \\
\hline 3. & Polyporales & Microporus & Microporus xanthopus & - & - & + \\
\hline
\end{tabular}

Keterangan : T (Tanah); BL (Batang Lapuk); RL (Ranting Lapuk)

Tabel 2. Faktor Lingkungan di Habitat Rawa Gambut, Kawasan Cabang Panti Taman Nasional Gunung Palung

\begin{tabular}{cc}
\hline Faktor Lingkungan & Hasil Pengukuran \\
\hline Suhu $\left({ }^{\circ} \mathrm{C}\right)$ & $27-28$ \\
pH substrat & 5,6 \\
Kelembapan (\%) & 99 \\
Intensitas Cahaya (Lux) & $15-23$ \\
Ketinggian (mdpl) & $32-38$ \\
\hline
\end{tabular}

\section{PEMBAHASAN}

Pada umumnya tubuh buah jamur anggota ordo Agaricales memiliki bentuk seperti payung dengan tangkai terletak sentral, didukung oleh tudung dan memiliki bilah. Tubuh buah jamur anggota ordo Agaricales biasanya berdaging yang terdiri dari hifa berdinding tipis dan mengembang (Kaul, 1997). Salah satu jamur dari ordo ini yaitu jamur anggota spesies Lichenomphalia sp. (Gambar 2.) memiliki tekstur tudung rapuh, permukaan berkerut (rugulose), garis tepi tudung bercuping dan berwarna coklat tua bening. Lamella melekat lurus (adnate), garis tepi rata dan berwarna coklat muda. Tangkai pada tudung sentral, permukaan tangkai berambut kaku (strigose) dan berwarna coklat tua. Tangkai melekat pada substrat batang kayu lapuk dengan cara menempel (inserted). Hal ini sesuai pernyataan Rehead et al. (2002) dalam Lodge et al. (2014), Lichenomphalia memiliki permukaan tudung luas dengan bagian tengah sedikit tertekan, memiliki tubuh buah dengan lamella yang melimpah (Omphalinoid), berkerut dengan lemah. Tudung berwarna abu-abu hingga kecoklatan. Tekstur tangkai menyerupai tulang rawan (kartilaginosa). Jamur ini dapat ditemukan pada batang atau cabang kayu mati (Corticioid).

Jamur anggota ordo Auriculariales merupakan ordo dari jamur lendir terbesar. Spesies dari ordo ini diketahui lebih banyak tumbuh diatas kayu (Alexopoulus et al., 1996). Jamur anggota famili Auriculariaceae terdiri dari tubuh buah yang beragam, mulai dari tekstur daging yang bergelatin, seperti lilin hingga gabus. Struktur Hymenium juga terdiri dari berbagai macam bentuk Hymenophore 
seperti halus dan berlipat (Yuan et al. 2018). Genus Auricularia merupakan anggota jamur yang paling umum dan terdistribusi luas, mulai dari tunggul, batang kayu hingga cabang pohon kayu. Kadang juga dapat ditemukan pada batang pohon besar yang masih hidup (Alexopoulus et al. 1996)

Jamur anggota spesies Auricularia auricula (Gambar 2.) memiliki permukaan tudung halus, bergelatin dan kenyal, garis tepi rata (entire) dan berwarna coklat muda. Lamella halus, berkerut, kering pada saat muda, berlendir jika sudah tua dan berwarna coklat bening. Auricularia auricula tidak memiliki tangkai buah (sessile). Auricularia ditemukan menempel pada batang kayu mati yang sudah lapuk. Miller \& Miller (2006) menyatakan bahwa $A$. auricula memiliki tubuh buah berukuran besar dan cukup tebal. Tekstur permukaan halus, bergelatin dengan warna oranye kecoklatan hingga merah kecoklatan. Pada permukaan bawah sering kali berkerut seperti jaringan, memiliki struktur daging yang cukup kuat, tidak mengeluarkan bau dan rasanya enak jika dimakan. Substrat jamur ini dapat ditemukan pada batang kayu lapuk dan umumnya jarang ditemukan pada batang kayu keras.

Jamur anggota spesies Auricularia delicata (Gambar 2.) memiliki tekstur kenyal, permukaan tudung berbulu jarang (minutely), garis tepi rata, berwarna coklat tua dan terdapat tonjolan ke atas pada pangkal. Permukaan bawah keriput bersilangan, garis tepi bergelombang (wavy) dan berwarna coklat bening. A. delicata tidak memiliki tangkai (sessile), dapat ditemukan pada dahan atau batang kayu yang sudah lapuk. Menurut Hubregtse (2017) A. delicata memiliki struktur lembut dan elastis. Tudung berwarna krim keabu-abuan hingga coklat dengan permukaan atas terdapat rambutrambut halus. Permukaan bawah tudung keriput dengan pola yang terbentuk seperti sarang lebah.

Polyporales biasanya tumbuh pada kayu dengan permukaan himenium berupa lubang-lubang kecil yang disebut pori-pori. Kebanyakan dari anggota ordo Polyporales memiliki tudung berbentuk papan rak dan sering disebut sebagai jamur bracket (mengurung). Anggota famili Polyporaceae memiliki ciri umum terdiri dari tudung, tangkai atau sessile, keras hingga liut atau berkayu saat tua (Kaul, 1997). Jenis jamur anggota famili Polyporaceae memiliki tubuh buah berukuran besar sehingga mempunyai kemampuan adaptasi yang baik pada berbagai kondisi lingkungan (Tampubolon et al., 2012). Salah satu jamur makroskopis anggota famili Polyporaceae yang ditemukan adalah jamur anggota genus Microporus.
Jamur ini memiliki tubuh buah berwarna cerah dan tangkai kecil (pendek). Permukaan bawah halus dengan pori-pori berukuran sangat kecil (Niemela \& Mrema, 2002). Jamur anggota spesies Microporus xanthopus (Gambar 2.) memiliki tekstur tudung liat seperti kulit dan permukaan berkerut halus, terdapat pola konsentris dan berwarna coklat kemerahan dengan garis tepi tudung bercuping. Permukaan bawah halus dan berwarna putih kusam. Tangkai terletak sentral, berwarna kuning atau coklat kekuningan dan permukaan halus. Perlekatan pada substrat menempel langsung, substrat tumbuh di ranting kayu lapuk. Menurut Florence \& Yesodharan (2000) M. xanthopus memiliki tubuh buah yang dapat hidup tahunan, tunggal atau bercabang, permukaan tudung berwarna coklat violet. Permukaan bawah berwarna putih kekuningan. Perlekatan tangkai jamur ditengah atau sedikit menjauh dari tengah, berwarna kuning atau coklat kekuningan, permukaan licin dan halus tanpa rambut.

Berdasarkan hasil pengukuran faktor lingkungan pada saat pengambilan sampel untuk masingmasing spesies jamur memiliki hasil yang berbeda. Pengukuran suhu pada lokasi tempat penelitian berkisar antara $27^{\circ} \mathrm{C}-28^{\circ} \mathrm{C}$. Menurut Alexopoulus (1996) suhu optimum untuk pertumbuhan jamur berkisar antara $25^{\circ} \mathrm{C}-30^{\circ} \mathrm{C}$. Pengukuran kelembapan udara pada lokasi penelitian di Taman Nasional Gunung Palung antara lain $99 \%$. Kelembaban yang terlalu tinggi diduga merupakan salah satu faktor yang menyebabkan hanya beberapa jamur saja yang dapat tumbuh pada habitat rawa gambut. Gandjar, et. al. (2006) menyatakan bahwa jamur dapat tumbuh pada kisaran kelembapan udara 70\% - 90\%. Menurut Kaul (1997), Faktor lingkungan yang paling jelas mempengaruhi pertumbuhan tubuh buah jamur berdaging adalah kelembapan dan temperatur. Kelembaban berperan penting pada pertumbuhan dan reproduksi jamur. Berdasarkan kelembabannya jamur dapat dibagi menjadi dua kategori antara lain spesies Xerophytic yang membutuhkan kelembaban rendah seperti polyporus dan Higrophytic yang mebutuhkan kelembaban tinggi (kebanyakan spesies berdaging). Polyporaes sebagian besar terdiri dari jamur yang dapat hidup tahunan atau bertahun-tahun, memiliki struktur keras, berkayu dan tidak memiliki lamella, sehingga ordo Polyporales hampir dapat ditemukan pada semua habitat.

Cahaya diperlukan bagi jamur untuk inisiasi primordia dan dapat mempengaruhi perkembangan tangkai, tudung, pembentukan himenium dan spora. Hasil pengukuran intensitas cahaya pada saat 
pengambilan sampel tiap spesies jamur yaitu berkisar antara 15 lux - 23 lux. Jamur tidak memerlukan cahaya dalam intensitas besar, terutama untuk jamur berdaging yang memiliki tekstur lembut dan berair. Menurut Kaul (1997), cahaya dapat menghambat perkembangan jamur karena efek pengeringannya. Intensitas cahaya pada setiap lokasi berbeda, hal ini dapat dikarenakan oleh tutupan tajuk yang tidak sama karena disebabkan oleh pohon tumbang.

Tanah gambut memiliki tingkat kesuburan rendah karena kandungan unsur haranya tidak tersedia secara bebas dan mengandung beragam asam-asam organik yang sebagian bersifat racun. Asam - asam tersebut merupakan bagian aktif dari tanah yang dapat menahan unsur hara pada tanah gambut (Agus \& Subiksa, 2008). Hasil pengukuran $\mathrm{pH}$ substrat tempat tumbuh jamur pada saat pengambilan sampel jamur sekitar 5,6. Gardner et al. (1991) menyatakan bahwa kebanyakan nutrient yang berguna bagi pertumbuhan jamur berada pada $\mathrm{pH}$

\section{DAFTAR PUSTAKA}

Agus, F \& Subiksa IGM, 2008, Lahan Gambut : Potensi untuk Pertanian dan Aspek Lingkungan, Balai Penelitian Tanah \& World Agroforestry Centre (ICRAF), Bogor

Alexopoulus, CJ, Mims, CW \& Blackwell, M, 1996, Introductory Mycology, John Wiley \& Sons, Inc. New York

Cannon, CH \& Leighton, M, 2004, 'Tree Species Distributions Across Five Habitats in a Bornean Rain Forest', Journal of Vegetation Science, vol. 15, hal. 257-266

Cannon, CH, Curran, LM, Marshall, AJ \& Leighton, M, 2007, 'Beyond Mast-Fruiting Events: Community Asynchrony and Individual Dormancy Dominate Woody Plant Reproductive Behavior Across Seven Bornean Forest Type', CURRENT SCIENCE, vol. 93 , no. 11

Darwis, W, Desnalianif \& Supriati, R, 2011, 'Inventarisasi Jamur yang Dapat Dikonsumsi dan Beracun yang Terdapat Di Hutan dan Sekitar Desa Tanjung Kemuning Kaur Bengkulu', Konservasi Hayati, vol. 7, no. 2, hal. 1-8

Florence, EJM \& Yesodharan, K, 2000, 'Macrofungal Flora of Peechi-Vazhani antara $6-7$. Hal ini menunjukkan bahwa $\mathrm{pH}$ yang dibutuhkan kurang untuk pertumbuhan jamur, sehingga diduga salah satu faktor ini lah yang menyebabkan sedikitnya jumlah jamur yang ditemukan pada lokasi rawa gambut.

Spesies jamur yang ditemukan di Taman Nasional Gunung Palung terdapat pada habitat Rawa Gambut yang tergolong kedalam jamur saprofit. Jamur yang tumbuh pada tanah tidak ditemukan, sedangkan yang tumbuh pada batang kayu lapuk sebanyak 3 spesies dan ranting kayu lapuk 1 spesies (Tabel 1). Hal ini diduga karena pada tanah gambut terdapat banyak bahan organik terutama yang berasal dari pelapukan batang kayu sehingga menjadi substrat tumbuh yang sesuai bagi jamur kayu, sedangkan pada lokasi lantai hutan rawa gambut terdapat pasang surut air genangan yang dapat dengan cepat merusak struktur tubuh buah jamur apabila terendam air, sehingga membuat jamur sulit untuk tumbuh dan berkembang di tanah.

Wildlife Sanctuary', Kerala Forest Research Institute

Gandjar, I, Sjamsuridzal, W, \& Oetari, A, 2006, Mikologi Dasar dan Terapan, Yayasan Obor Indonesia, Jakarta

Gardner, FP, Peaece, RB \& Mitchell, RL, 1991, Fisiologi Tanaman Budidaya, Herawati Susilo (Alih Bahasa), UI Press, Jakarta

Hubregtse, J, 2017, Fungi In Australia, The Field Naturalists Club of Victoria Inc, Victoria

Kaul, TN, 1997, Introduction To Mushroom Science, Science Publisher, Inc. U.S of America

Keizer, GJ, 2007, The Complete Encyclopedia Of Mushrooms, Rebo International, Netherlands

Lodge, DJ, Padamsee, M, Matheny, PB, Aime, MC, Cantrell, SA, Boertmann, D, Kovalenko, A, Vizzini, A, Dentinger, BTM, Kirk, PM, Ainsworth, AM, Moncalvo, JM, Vilgalys, R, Larsson, E, Lucking R, Griffith, GW, Smith, ME, Norvell, LL, Desjardin, DE, Redhead, SA, Ovrebo, CL, Lickey, EB, Ercole, E, Hughes, KW, Courtecuisse, R, Young, A, Binder, M, Minnis, AM, Lindner, DL, Santana, BO, Haight, J, Laessoes, T, Baroni, TJ, Geml, J \& Hattori, T, 2014, 'Molecular Phylogeny, Morphology, Pigment Chemistry and Ecology in Hygrophoraceae 
(Agaricales)', Fungal Diversity, vol. 64, no. 1, hal. 1-99

Mcknight, KH \& Mcknight, VB, 1987, A Field Guide to Mushrooms of North America, Houghton Mifflin Company Boston, New York

Miller, OK \& Miller, HH, 2006, North American Mushrooms, Falcon Guide, U.S of America

Niemela, T \& Mrema, FA, 2002, 'Newtonia Buchananii and Its Fungal Decayers In Natural Stands', Karstenia, vol. 42, hal. 4966

Nurilla , N, Setyobudi, L \& Nihayati, E, 2013, 'Studi Pertumbuhan dan Produksi Jamur Kuping (Auricularia auricula) Pada Substrat Serbuk Gergaji Kayu dan Serbuk Sabut Kelapa', Jurnal Produksi Tanaman, vol. 1, no. 3, hal. 40-47

Ornely, OBJ, Calixte, ENH, Roger NAG, Leonid, NMMR, Cedric, SO, Privat, OJ \& Clement, OEL, 2018, 'Chemical Screening, Antioxidant Potential and Antiangiogenic Effect of Microporus xanthopus (fr.) Kuntze, Ganoderma orbiforme (fr.) Ryvarden and Polyporus fasciculatus (pat) llyod, Medicinal Mushrooms from Gabon', American Journal of Pharmacy and Health Research, vol. 6, no. 10, hal. 14-29
Sundra, IK, 2016, Metode dan Teknik Analisis Flora dan Fauna Darat, Universitas Udayana, Denpasar

Tampubolon, SDBM, Utomo, B \& Yunasfi, 2012, 'Keanekaragaman Jamur Makroskopis di Hutan Pendidikan Universitas Sumatra Utara Desa Tongkoh Kabupaten Karo Sumatra Utara', Fakultas Pertanian, Universitas Sumatra Utara

Tapwal, A, Kumar, R, \& Pandey, S, 2013, 'Diversity and Frequency of Macrofungi Associated With Wet Ever Green Tropical Forest in Assam, India', Biodiversitas, vol. 14, no. 2, hal. 73-78

Wahyudi, AE, Linda, R \& Khotimah, S, 2012, 'Inventarisasi Jamur Makroskopis di Hutan Rawa Gambut Desa Teluk Bakung Kecamatan Sungai Ambawang Kabupaten Kubu Raya', Protobiont, vol. 1, no. 1, hal. 811

Widhiastuti, R, \& Nurtjahja, K, 2013, Biodiversitas dan Identifikasi Cendawan, USU Press, Medan.

Yuan, HS, Lu, X \& Decock, C, 2018, 'Molecular and Morphological Evidence Reveal a New Genus and Species in Auriculariales from Tropical China', MycoKeys, vol. 35, hal. 2739 